\title{
Cervical intraepitheial neoplasm with ichthyosis uteri- A case report
}

\author{
Malla Vaidya Karishma ${ }^{1}$, Shrestha Bigya ${ }^{1}$ \\ ${ }^{I}$ Paropakar maternity and women hospital, Kathmandu, Nepal.
}

\section{Keywords: \\ Cervical intraepithelial \\ lesion; \\ Ichthyosis; \\ Metaplastic;}

\begin{abstract}
A rare condition in which the entire surface of the endometrium is replaced by stratified squamous epithelium is called Ichthyosis uteri. Originally described as an endometrial response to iatrogenicallyintroduced caustic substances, similar changes have since been described in association with a variety of inflammatory conditions of the endometrium.
\end{abstract}

Here we report a case of intraepithelial neoplasm III, with ichthyosis uteri. A 75-years-old female with hypetension, underwent total abdominal hysterectomy with bilateral salphingo-ophorectomy for watery discharge per vaginal since four months.

\section{Correspondence:}

Dr. Karishma Malla Vaidya, MBBS, $M D$

Sr Consultant, Department of Pathology,

Paropakar Maternity and Women's Hospital, Kathmandu, Nepal

Email:rupkari@yahoo.com

ORCID ID: 000-0002-5035-9631

Reveived : August $31^{\text {st }} 2017$; Accepted : December $7^{\text {th }}$ 2017; Published : March $30^{\text {th }} 2018$

Citation: Malla KV, Shrestha B. Cervical intraepitheial neoplasm with ichthyosis uteri- A case report. J Pathol Nep 2018;8:1320-2. doi: 10.3126/jpn.v8i1.19463

Copyright: This is an open-access article distributed under the terms of the Creative Commons Attribution 4.0 International License, which permits unrestricted use, distribution, and reproduction in any medium, provided the original author and source are credited.

\section{INTRODUCTION}

Cervical intraepithelial lesion (CIN) is a premalignant condition with abnormal growth of squamous cells on the surface of the cervix. ${ }^{1} \mathrm{CIN}$ remains stable in most of the cases, or eliminated by the host's immune system without intervention. ${ }^{2}$ However, a small percentage of case progresses to become cervical cancer, usually squamous cell carcinoma (SCC), when left untreated. ${ }^{3}$ The risk of progression to invasive cancer increases with time and the time required is shorter with increasing severity of the lesion. Cervical squamous cell carcinoma can directly invade the uterine wall with or without parametrial involvement or by lymphatic invasion. Direct extension to the endometrium replacing it without myometrial invasion is very uncommon. ${ }^{4}$

Ichthyosis uteri, is an exceedingly rare condition in which the surface of the endometrium is completely or nearcompletely replaced by squamous epithelium. Originally described as an endometrial response to iatrogenicallyintroduced caustic substances, similar changes have since been described in association with a variety of inflammatory conditions of the endometrium. ${ }^{5}$ Here we report a case with 


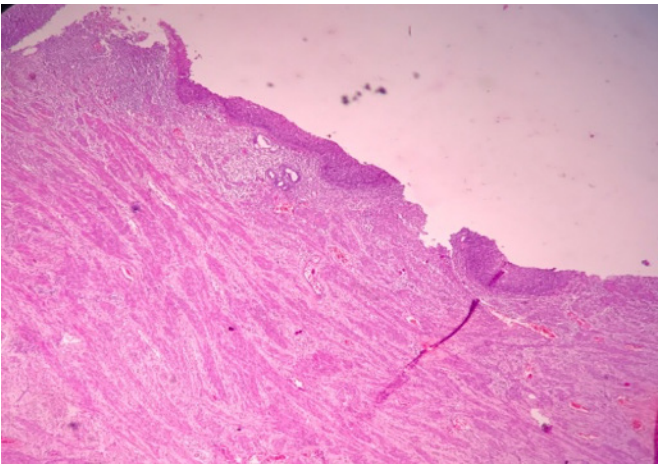

Figure 1: Replacement of endometrium lining by stratified squamous epithelium (HE stain, X40).

associated CIN 3 with surface of endometrium completely replaced by squamous epithelium.

\section{CASE REPORT}

A 75 years-old-female presented with watery discharge per vagina for four months and lower back pain from last 2 years. She had menopause 25 years back. There was no history of spotting, per vagina bleeding or lower abdomen pain. Her past history revealed hypertensive and arthritis for which she was under medication. No history of tuberculosis, inflammatory conditions of the uterus or iatrogenically introduced substances were found. On clinical examination she had eight week size anteverted firm uterus. Cervix showed sign of discharge with VIA positive on colposcopy with no obvious growth. The patient underwent a total abdominal hysterectomy, bilateral salpingo-oophorectomy. There was $30 \mathrm{ml}$ of pus in uterine cavity. The pus culture showed no growth. The procedure was well-tolerated without having any complications.

Gross examination: Specimen consisted of uterus with bilateral tubes and ovaries. Uterus measured $8 \times 6.5 \times 2.5 \mathrm{~cm}$. Endometrial cavity measured $3.7 \times 0.5 \mathrm{~cm}$ with tan to tanbrown area extending from cavity to endocervix and into the lower uterine segment. Endocervical canal measured $3.0 \mathrm{~cm}$ in length and external os measured $0.6 \mathrm{~cm}$. Erosion was noted in cervix. Right tube measures $3.5 \times 0.5 \mathrm{~cm}$ and right ovary was cystic, measuring $2 \times 1.5 \mathrm{~cm}$. Cut section showed cystic structure measuring $0.5 \mathrm{~cm}$, containing clear fluids. Left tube measured $4.5 \times 0.5 \mathrm{~cm}$ and left ovary measured $1.5 \times 1.0 \times 0.5 \mathrm{~cm}$, cut section showed greyish brown areas.

Microscopic examination: Sections from endometrium showed the entire endometrial surface is lined by nonkeratinized stratified squamous epithelium revealing fullthickness dysplasia (fig.1). The endometrial gland and stroma beneath the surface were in proliferative phase. (fig.2) Section from cervix showed stratified squamous epithelium revealing loss of polarity and full thickness dysplasia with intact basement membrane (fig.3). The individual cells showed pleomorphism with high $\mathrm{N}: \mathrm{C}$ ratio, enlarged irregular, hyperchromatic nuclei, prominent

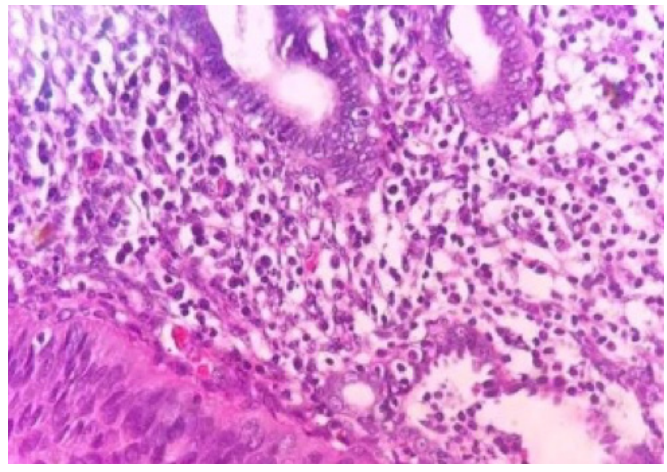

Figure 2: Stratified squamous epithelial lining showing features of dysplasia. Note the presence of endometrial glands within the stroma (HE stain, X100).

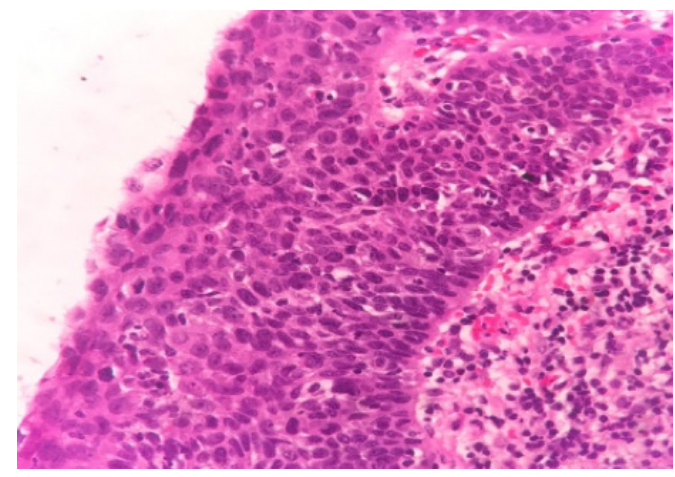

Figure 3: Stratified squamous epithelium of cervix showing full thickness dysplasia ( HE stain, X 100).

nucleoli. Mitotic figures were also seen up to middle third of epithelium. The underling stroma showed chronic inflammatory cells consisting of lymphocytes. Normal looking endocervical glands were also noted. The section from right ovary showed cystic structures lined by benign cuboidal epithelium resembling features of simple cyst.

\section{DISCUSSION}

The case reported here is a cervical intraepithelial neoplasm grade 3 associated with extensive ichthyosis uteri-like changes of the endometrium that, additionally, had superimposed high-grade dysplastic changes. A case of carcinoma in situ of cervix with contiguous extension to the endometrium of the lower uterine segment is reported by Rajeshwari K Muthusamy et. al in their study. ${ }^{6}$ This histology findings may be explained due to viral infection in the cervix by HPV which lead to, a cervical intraepithelial neoplasm grade 3 originated in the cervix and the extended proximally, ichthyosis uteri. Oluwole Fadare in their study shows HPV positive in ichthyosis uteri with squamous cell carcinoma. $^{5}$

The term "ichthyosis uteri" was initially coined in 1885 by Zeller to refer to extensive squamous metaplasia of the surface endometrium following iatrogenically-introduced caustic substances such as formalin or iodine. ${ }^{7}$ Since that 
initial report, the term "ichthyosis uteri" and the phenomenon it describes have become well accepted but have been used only sporadically in the literature. ${ }^{8,9}$ Squamous metaplasia, a normal physiological process, is encountered frequently in cervical biopsies and loop electrosurgical excision procedures. The metaplastic cells are generally uniform, round to oval, with a single nucleolus. The nuclear contours are generally smooth. The presence of significant cellular crowding, nuclear atypia and increased mitotic figures in the upper half of the epithelium can be the most helpful morphological features in supporting a diagnosis of high $\square$ grade CIN..$^{10}$ Here they have all these features extended up to the surface of endometrium. Ichthyosis is considered as benign condition. However, anaplastic and dysplastic changes have been reported by some authors., ${ }^{9,11,12}$

A case reported by Oluwole Fadare in 2006 showed 38 years female with complain of vaginal discharge with past medical history of acquired immune deficiency and the age group was in concordance with our case. Nishu Bhardwaj et $\mathrm{al}^{13}$ and Kanchan Murhekar, Urmila Majhi, et al ${ }^{14}$ shows dysplastic features in older age group. Pins et al described a case in which high-grade dysplasia of the cervix extended proximally and coated the entire endometrium. ${ }^{12}$ Bewtra et $\mathrm{al}^{15}$ described a case of extensive benign squamous keratinization with underlying endometrial adenocarcinoma. Besides the dysplastic or anaplastic changes, a case of malignant degeneration has also been reported in ichthyosis uteri. ${ }^{16}$ This case presented as a CIN III at the base of ichthyosis uteri. The ichthyosis uteri developed over a period of just three years from a discrete squamous cell metaplasia of the endometrial body in the presence of slight nonspecific endometritis. Our case closely resembles the case described by Heckeroth and Ziegler. ${ }^{16}$

\section{Conflict of Interest: None}

\section{REFERENCES}

1. Kumar, V, Abbas A K., Fausto N, Mitchell R N. Cervical Dysplasia: Overview, Risk Factors, In: Robbins Basic Pathology 8thed. Saunders Elsevie;. Philadelphia. 2007. pp718-21.

2. ACOG Committee Opinion No. 463: Cervical cancer in adolescents: screening, evaluation, and management. Obstet Gynecol. 2010;116:469-72. Crossref

3. Agorastos T, Miliaras D, Lambropoulos A, Chrisafi S, Kotsis A and Manthos A. Detection and typing of human papillomavirus DNA in uterine cervices with coexistent grade I and grade III intraepithelial neoplasia: biologic progression or independent lesions?".Eur J Obstet Gynecol Reprod Biol. 2005;121:99-103. Crossref

4. Agashe SR, Kulkarni MP, Momin YA, Sulhyan KR. Superficial extension of squamous cell carcinoma in situ of cervix involving endometrium, bilateral fallopian tubes and ovaries: A case report. Indian J Pathol Microbiol. 2007;50:375-7. Crossref
5. Oluwole Fadare. Dysplastic Ichthyosis Uteri-like changes of the entire endometrium associated with a squamous cell carcinoma of the uterine cervix. Diagn Pathol. 2006;1:8. $\underline{\text { Crossref }}$

6. Muthusamy RK and Mehta SS. Squamous Cell Carcinoma In situ of the Cervix with Superficial Intraepithelial Extension to the Endometrium of Lower Uterine Segment: A Rare Presentation. Indian J Med Paediatr Oncol. 2017;38:88-9. $\underline{\text { Crossref }}$

7. Marcus SL. Adenoacanthoma of the endometrium: a report of 24 cases and a review of squamous metaplasia. Am J Obstet Gynecol. 1961;81:259-67. Crossref

8. Bewtra C, Xie QM, Hunter WJ, Jurgensen W. Ichthyosis uteri: a case report and review of the literature. Arch Pathol Lab Med. 2005;129: e124-5. Crossref

9. Zaino RJ. Metaplasia. In: Silverberg SG, editor. Interpretation of endometrial biopsies and curettings. Philadelphia: Lippincott-Raven; 1996. pp. 241-61.

10. Our approach to squamous intraepithelial lesions of the uterine cervix .J Clin Pathol. 2007; 60: 449-55. $\underline{\text { Crossref }}$

11. Patton WT, Squares GV: Ichthyosis uteri. A case report. Am J Obstet Gynecol. 1962;84: 858-60 $\underline{\text { Crossref }}$

12. Pins MR, Young RH, Crum CP, Leach IH, Scully RE: Cervical squamous cell carcinoma in situ with intraepithelial extension to the upper genital tract and invasion of tubes and ovaries: report of a case with human papilloma virus analysis. Int $\mathrm{J}$ Gynecol Pathol.1997;16:272-8. $\underline{\text { Crossref }}$

13. Bhardwaj N, Diwaker P, Gogoi P, Wadhwa N, Mishra K. Ichthyosis Uteri Associated with Endometrial Adenocarcinoma: A Case Report. J Clin Diagn Res 2017;11:ED24-ED5. Crossref

14. Murheka Kr,Majhi U, Sridevi V, T Rajkumar. Does "ichthyosis uteri" have malignant potential? : A case report of squamous cell carcinoma of endometrium associated with extensive ichthyosis uteri. Diagn Pathol 2008;3:4. $\underline{\text { Crossref }}$

15. Bewtra C, Xie QM, Hunter WJ, Jurgensen W: Ichthyosis uteri: a case report and review of literature. Arch Pathol Lab Med. 2005;129:e1245. $\underline{\text { Crossref }}$

16. Heckeroth V, Ziegler HK: Ichthyosis uteri. Case report on a rate clinical entity. Geburtshilfe Frauenheilkd. 1986;46:248-9. Crossref 